\title{
28 Research Soure \\ Landscape -scale habitat associations in an urban Stock Dove Columba oenas population
}

James Elliot Richardson ( $\nabla$ james@e-richardson.uk)

Manchester Metropolitan University https://orcid.org/0000-0002-5573-4277

Alexander Lees

Manchester Metropolitan University - All Saints Campus: Manchester Metropolitan University

Stuart Marsden

Manchester Metropolitan University - All Saints Campus: Manchester Metropolitan University

\section{Research Article}

Keywords: citizen science, eBird, urban matrix, spatial scales, avian habitat selection

Posted Date: June 28th, 2021

DOI: https://doi.org/10.21203/rs.3.rs-320608/v1

License: (1) This work is licensed under a Creative Commons Attribution 4.0 International License.

Read Full License 


\section{Abstract}

While some species are known to thrive in urban areas, urban expansion is a major driver of biodiversity loss. Columbids such as feral Rock Doves Columba livia domestica and Common Woodpigeon Columba palumbus have adapted extremely well to the urban environment in Europe and beyond, but the Stock Dove Columba oenas, a bird of farmland and woodland edge in the UK and of national conservation concern, is encountered far more rarely in urban areas. Here we explore the multi-scale landscape associations of the little-studied Stock Dove within the urban matrix of Greater Manchester, UK, as a step towards identifying its long-term conservation needs. We built a pilot model from historical citizen science records to identify potentially occupied patches within the city, and then surveyed these patches for Stock Dove during Spring 2019. We combined the survey results with citizen science records from the same period. We described the habitat and landscape characteristics of these patches using four variables at different scales and twelve unscaled variables. We used a three-stage random forest approach to identify a subset of these variables for interpretation and a subset for prediction for the presence of Stock Dove within these patches. Key variables for predicting Stock Dove presence were their relative abundance in the region immediately beyond the core urban area, the greenness (NDVI) of the environment around patches, and the canopy cover of individual trees over $20 \mathrm{~m}$ high within patches. Stock Doves tended to be associated with habitats with more surface water during the non-breeding season than the breeding season. Our results highlight the importance of large trees within urban greenspace and the importance of softer boundaries around urban patches for Stock Doves. While Stock Dove share many traits with species that are successful in the urban environment, they remain relatively poor urban adapters.

\section{Introduction}

Urbanisation drives the loss, degradation and fragmentation of natural habitats (Bar-Massada et al. 2014; McKinney 2006). Urban matrices typically consist of a patchwork of different habitats, of varying size and quality (Crooks et al. 2004; Davis et al. 2014) in addition to offering entirely novel habitats with no historical analogues (Werner, 2011). Urbanisation consequently results in biodiversity loss and turnover, favouring generalist species that adapt better to novel environments over specialist species (Werner 2011) which can drive the homogenisation of urban wildlife assemblages (Chace and Walsh 2006). Increasing urbanisation may lead to an increase in animal biomass but a decrease in species richness (Chace and Walsh 2006) and an increase in non-native species (McKinney 2006). However, cities that retain more remnant habitat are more likely to retain native species (Chace and Walsh 2006).

Analysis of urban biodiversity levels has often focused on the rural-urban gradient (Nielsen et al. 2014; Beninde et al. 2015), a focus which may miss variation in the underlying structure of the urban matrix of different cities (Werner 2011; Beninde et al. 2015). Instead, an approach that identifies individual habitats as urban patches (sometimes referred to as urban greenspaces) within an interconnected urban matrix allows a more finely grained understanding of species response to urbanisation to be gained (Aronson et al. 2017). Patches are connected by their proximity to others or by functional habitat corridors (Lepczyk et 
al. 2017) such as river valleys, off-road cycle routes, canals, or wooded streets. Species response to urbanisation can then be understood by local habitat features determining habitat suitability and landscape features defining the permeability of the landscape for species dispersal (Beninde et al. 2015). The response of an individual species to these habitat and landscape features will vary due to speciesspecific niche requirements (Jokimäki et al. 2016) and dispersal ability (Martin et al. 2017). Thus, while a patch might provide the required habitat and the landscape the required corridors for dispersal, a species' life history may still prevent settling in a patch. This could be due to either failure to adapt to novel resources available in the urban environment (Spotswood et al. 2021; Shochat et al. 2006), or due to intraspecific competition (Lees 2018).

The pigeons and doves Columbidae are a speciose avian family including some consistent urban adaptors across most of the world (Sol et al. 2014). In the UK,_for example, there are large urban populations of commensal feral Rock Doves Columba livia domestica (McKinney 2006; Isaksson 2018) as well as Common Woodpigeons Columba palumbus (hereafter Woodpigeons) and Collared Doves Streptopelia decaocto. In rural and agricultural habitats Woodpigeons occur in sympatry with Stock Doves Columba oenas (Snow et al. 1998; Murton et al. 1964). Although widespread, there are estimated to be just 320,000 Stock Dove territories in the UK compared with an estimated 5,400,000 Woodpigeon territories (Woodward et al. 2020). While Woodpigeons have adapted to the urban environment (Fey et al. 2015; Ó hUallacháin 2014; Bea et al. 2011), Stock Doves remain uncommon in urban areas (Robinson 2005). A major life history difference between the two species is their choice of nest sites; Stock Dove are cavity nesters whereas Woodpigeon nest on open branches. Stock Doves prefer ecotonal areas between woodland and open country where mature trees have cavities and hollows for nesting but are within easy access of fields for foraging as well as close to a source of convenient drinking water (Snow et al. 1998). Nest site requirements may well affect Stock Dove's urban abundance as tree cavities are sparser in urban areas when compared to continuous woodland (Davis et al. 2014). Stock Doves have suffered recent declines in the UK, which holds an important European breeding population, (Robinson 2005) and are classified as Amber under the Birds of Conservation Concern 4: The Red List for Birds (2015). Understanding their habitat requirements is a necessary step towards improving their conservation status.

We aim to understand the spatial distribution of Stock Dove in Manchester, a major UK city, and to identify the landscape-scale predictors that best explain this distribution. We undertook a field survey across Greater Manchester to identify patches occupied by Stock Dove and combined the results with citizen science data. We then identify the predictors for the landscape and habitat associations of Stock Dove based on the field survey results. Finally, we explore differences in habitat and landscape associations between the breeding and non-breeding season.

\section{Methods}

\section{Study Area}


Greater Manchester $\left(53^{\circ} 29^{\prime} \mathrm{N} 2^{\circ} 14^{\prime} \mathrm{W}\right)$ is a metropolitan county in the North West of England with a population of 2.8 million. The metropolitan county is close to sea level with a mean elevation of $38 \mathrm{~m}$ and a temperate oceanic climate. The M60 ring-road forms an obvious physical border around the city and contains parts of the metropolitan boroughs (local administrative districts) of Manchester, Salford, Trafford, Stockport, Tameside, Rochdale and Bury. Manchester (metropolitan borough), which is mostly retained within the M60 ring-road, is $20.4 \%$ greenspace and therefore the $8^{\text {th }}$ greenest city in the UK (The Guardian, 2017). That greenspace consists of patches of remnant woodland, brownfield regrowth, local nature reserves (LNR), managed parkland, cemeteries, and sports fields. The greenspaces are connected via canals, rivers, green cycleways, and treelined streets.

\section{Citizen Science Records}

We used citizen science data from eBird (eBird 2019), The Manchester Birding website (Manchester Birding 2019) and Bird Track (BTO 2019) to provide a list of previous Stock Dove records from inside the Manchester M60 ring-road. These were combined to produce a list of every patch within the M60 ringroad that had a previous sighting recorded (Figure 1). These records included the patch name, the record source, and the date and time of the observation.

\section{Survey}

A field survey was undertaken between 1 March-31 May 2019 to identify greenspaces within the M60 ring-road occupied by Stock Doves. Potential patches occupied by Stock Dove were identified using a 'pilot' maxent model built using the citizen science records along with environmental data from the Ordnance Survey and Forestry Commission (Appendix I). JR visited each of the potential patches twice during the survey period, during which every hectare was visited, and each survey took at least 2.5 minutes per hectare for open habitat and up to 5 minutes per hectare for patches with more closed habitat. Additionally, in May 2019 JR visited patches that had previous Stock Dove sightings recorded but had not yet had a recording made during the survey period. In these patches, where possible, JR used knowledge from the person who had made the previous record to target his visits to the most probable areas of those patches.

For the survey results, presence records were created for each patch where either Stock Dove were found during a survey; an eBird checklist was submitted containing a Stock Dove; a sighting was recorded on Manchester Birding; or a sighting was sent to us from the South Manchester Raptor Group. Absence records were created for each patch that was identified to be surveyed and JR failed to find Stock Dove during the survey period; or had an area of at least $0.25 \mathrm{~km}^{2}$ and had at least one visit recorded on either eBird or Manchester Birding during the survey period which did not list Stock Dove.

\section{Predictor Variables}


Stock Dove require habitat with large trees for cavity nesting, ideally close to both water and to grassland for foraging (Snow 1998). Additionally, as we want to test the position of that habitat within the wider landscape, landscape variables for distance from city centre, surrounding greenness (NDVI), and surrounding levels of Stock Dove relative abundance were included from the British Trust for Ornithology (BTO) (2019b). Spatial variables were measured using a shape file containing vectors for each surveyed patch which came from the Ordnance Survey Greenspace dataset (Ordnance Survey 2018a), the LNR dataset (Natural England 2020), or were created using QGIS (QGIS Development Team 2019) based on the Open Street Map (OpenStreetMap contributors 2015).

\section{Modelling Approach}

We used the random forest approach of Genuer et al. (2010) designed for high dimensional problems where the number of predictors $(p)$ is high compared to the number of samples $(n)$. This approach has been shown to work well in the field of ecology (Fox et al. 2017) and has been previously adapted for selecting the appropriate scale of landscape variables (Bradter et al. 2013). The approach has three stages, a ranking stage, a removal stage, and then a selection stage. We then alter the selection stage depending on whether the aim is to find predictor variables highly related to the response variable for interpretation purposes, or to find predictor variables for building a prediction model (Figure 2). The first stage ranks the variables based on their average importance from 50 runs with 2000 trees in each forest. The second stage drops variables when the standard deviation of their importance is below the minimum prediction value of the CART model fitted to the curve of all predictor variables' standard deviations (Genuer et al. 2010).

The final stage for selecting variables for interpretation computes the error rate of random forests from 50 runs of nested models starting with the model with the single most important predictor variable and then adding each remaining predictor variable in turn. A minimal model is selected with an error rate below the lowest error rate augmented by standard deviation. In contrast, the final stage for selecting variables for prediction again starts with the most important predictor variable and then adds in each remaining variable in turn, however, a variable is only added when the error rate exceeds a threshold. The threshold is set to the mean of the absolute values of the first order differentiated out of the bag (OOB) errors between the model selected for interpretation and the one with all predictors, this ensures the error decrease from adding additional predictors is greater than variation added by noisy predictors (Genuer et al. 2010). The prediction model is likely to contain more variables than the interpretation model.

To select the most appropriate spatial scale for the scaled variables, the first stage of this approach was initially run with every predictor variable at every scale. The highest ranked scale for each variable was then selected and all other scales were discarded. The first stage was then repeated with just the 'best' scale for each scaled variable, the rest of the approach was then followed in full, and two models were selected: one for interpretation and one for prediction (Figure 2). Finally, a random forest model was generated from the survey data using the variables selected for prediction, probabilities were generated 
for each patch from the OS Greenspace data set (Ordnance Survey 2018a) using the R random forest package (Liew and Wiener 2002).

To understand if there is a season variation in Stock Dove distribution the historical sightings, from eBird (2019), Bird Track (BTO 2019) and Manchester Birding (2019), were examined to see if the landscape and habitat predictor variables identified from the survey data varied between breeding and non-breeding seasons. The historical citizen science records (before 2019) were split into breeding (March - August inclusive) and non-breeding season (September - February inclusive) and then reduced to ensure there was at most one presence record per patch per annual season. Wilcoxon signed-ranked tests were then completed for each predictor variable to compare the means between the breeding and non-breeding season patches.

\section{Results}

\section{Field Survey Results}

In total, 65 patches were included in the analysis. Stock Doves were found at 28 of these patches during the survey period (Figure 3). Stock Doves were found on patches that included nine LNRs, eight parks, four playing fields, four golf courses, and a water treatment works, a cemetery and cycling infrastructure (the full list of 65 patches included 20 LNR, 20 parks, eight playing fields, seven golf courses, four cemeteries, and then cycling infrastructure and a water treatment works). The 65 patches included 28 patches visited during the survey, 23 patches where Stock Dove were recorded in citizen science or by the South Manchester Raptor Group, and 14 patches which were added as absences using the absence criteria. The area of the 65 patches averaged $0.4 \pm 0.49 \mathrm{~km}^{2}\left(0.04-2.9 \mathrm{~km}^{2}\right)$ compared to the area of the 28 presence patches which averaged $0.51 \pm 0.69 \mathrm{~km}^{2}\left(0.04-2.9 \mathrm{~km}^{2}\right)$. Eight of the 28 presence patches were patches identified from the pilot maxent model where Stock Dove had not previously been recorded. Many presence sites lay along rivers, either the Mersey in the South, or the Irwell in the North.

\section{Landscape and Habitat Associations}

The spatial scales selected were a $13 \mathrm{~km}$ buffer around patches for average BTO relative abundance; a $500 \mathrm{~m}$ buffer around patches for average NDVl; $20 \mathrm{~m}$ for the density of individual trees above a certain height; and $20 \mathrm{~m}$ for the density of individual trees above a certain height. This left 16 variables which were entered for variable selection. The first two stages of Geneur's method reduced these 16 variables to six (Table 2), of these the top three were selected for interpretation and the top five were selected for a prediction model.

The prediction model shows a clustering of potentially suitable patches in the northwest and south of Manchester (Figure 4). This distribution mirrors the average BTO relative abundance around Manchester. The average BTO relative abundance of Stock Dove within the M60 ring-road is lower (2.2) than the more 
rural areas in the $13 \mathrm{~km}$ buffer outside the ring-road (4.2). Moreover, the average relative abundance within the $13 \mathrm{~km}$ buffer is higher in the West than in the East, which mirrors Stock Dove being found in the West of the urban area (average relative abundance within each quarter of the $13 \mathrm{~km}$ buffer: northwest 4.2 , southwest 6.2 , northeast 3.0 , southeast, 3.7 ).

The citizen science data contained records from 38 patches, with 36 patches in the breeding season and 25 patches in the non-breeding season. The non-breeding season added just two additional patches which had no records during the breeding season. The only predictor variable to have a significant difference between the breeding and non-breeding season was the total area covered by water. Patches with Stock Dove in the non-breeding season had a larger area of water cover than those in the nonbreeding season (Table 3). There was also a near-significant difference in the total area covered by grassland, suggesting that Stock Dove may choose more open habitats in the non-breeding season. There was no significant difference between the function of the patches used between breeding and nonbreeding seasons $\left(\chi^{2}=5.65 d f=8, p=0.69\right)$, however, there are four samples in the breeding season for golf courses but none in the non-breeding season.

\section{Discussion}

Ours is the first detailed study of the spatial distribution and habitat choice of Stock Doves within an urban environment and provides insight into the impacts of urbanisation on the species. We found Stock Doves to be largely restricted to 'greener' habitat patches with large trees geographically proximate to rural source populations. Stock Doves are more abundant in the lowland arable and 'mossland' landscapes west of the city than in the upland moorland fringe to the east (BTO 2019b; Figure 1). These broader scale differences in abundance likely lined to topoedaphic differences which define habitat quality for Stock Doves may explain the relative rarity of the species in the eastern half of the city in comparison to the west - if areas outside of the city are important as source populations for colonists of the urban area. The higher levels of NDVI around occupied patches indicate a preference for greener areas of the city (Purevdorj et al. 1998), indicating that the amount of landscape-level greenspace is also important and not just patch-level characteristics.

Species responses to urbanisation depends on their niche requirements (Jokimäki et al. 2016); we have shown that large trees are important in explaining Stock Dove's distribution, as the species is a secondary cavity nester (Kosiński et al. 2011). These larger trees are more likely to offer suitable nest holes, with trees over $20 \mathrm{~m}$ high selected in two different predictor variables at different spatial scales. Previous studies have shown that Stock Dove prefer nest sites in large Scots Pine Pinus sylvestris or Beech Fagus spp. with two or more cavities (Kosiński et al. 2011) and taller trees are more likely to have more cavities (Struebig et al. 2013). Urbanisation benefits cavity nesters over ground nesters, as cavity nesters may more readily adapt to manmade cavities (Jokimäki et al. 2016) which may a necessity if the number of natural cavities in urban environments is lower (Davis et al. 2014; Newson et al. 2011). 
Cavity availability may be further reduced by interspecific competition with other cavity nesters (Strubbe and Matthysen 2007), in the context of our study and elsewhere in the UK, this may include native Tawny Owls Strix aluco and introduced Grey Squirrel Sciurus carolinensis and, in some cities, including Manchester Ring-necked Parakeets Psittacula krameria. Neither of these latter two species have been found to have a demonstrable impact on the abundance of native cavity nesters (Craig et al. 2016; Hewson and Fuller 2003; Newson et al. 2009; Newson et al. 2011; Strubbe and Matthysen 2007), they could still have a significant impact on cavity availability and suppress the abundance of other species without being the primary driver of community change (Didham et al. 2005). With insufficient large cavities, nesting sites could be a limiting factor for Stock Doves' success in the urban environment. Given that we found Stock Doves using raptor nest boxes during our field survey, a behaviour which is well known (Møller et al. 2016) then provisioning of nest boxes may be one way of boosting Stock Dove reproductive success in cities.

Stock Dove are primarily granivorous (Snow et al 1998) and urbanisation often favours granivores in Europe (Jokimäki et al. 2016). Stock Dove have been found to respond positively to grassland improvement (when inorganic fertilizer has been added) than in unimproved grassland due to an increase in grass seed available (Barnett et al. 2004) but in this study we did not differentiate between types of grassland (such that monocultural playing fields were lumped with pasture and grassland managed for wildlife). Therefore, the effect of grassland type may have been masked in our study. Stock Doves are reported to feed on seeds on the ground (Snow et al, 1998) and in a study of the species in inner London Goodwin (1960) records that he only saw Stock Dove feeding on the ground twice - we only recorded the species feeding on the ground on four occasions during our survey (in Broadoak Park, Platt Fields Park, and Reddish Vale LNR). Thus, food availability could also be a limiting factor for Stock Dove within the urban environment.

While there is potentially suitable habitat available in urban areas, Stock Dove may need to cross substantial areas of unsuitable habitat to find suitable patches. Habitat loss and land use intensification increases the costs of dispersal for dispersive species more so than for sedentary species like Stock Doves (Martin et al. 2017). During our field survey we observed Stock Doves using habitat corridors such as cycle paths, canals and rivers, - dispersing birds following these linear features into the city may be more likely to find suitable breeding habitat. However, in Madrid there was no evidence of Stock Doves using treelined streets despite other ground-feeding (Woodpigeon, Blackbird Turdus merula, Common Starling Sturnus vulgaris and European Serin Serinus serinus) and cavity-nesting (Coal Tit Periparus ater and Great Tit Parus major) species using them (Fernández-Juricic 2000). The significance of high NDVI around patches with Stock Dove also indicates that they prefer patches without hard edges; this sensitivity to edge effects may limit their ability to occupy many urban areas (With and King 2001). This edge sensitivity is reinforced by the finding that the species has a clear preference for habitat away from roads in farmland in England (Fuller et al. 2001) a preference for the interior of parks in Spain where Woodpigeon were found largely at the park edges (Fernández-Juricic 2001). The edge effect from roads may not only relate to habitat fragmentation but also noise pollution (Šálek et al. 2010) and it may be that Stock Dove are sensitive to other anthropogenic sound sources. 
While Stock Dove exhibit some traits associated with urban adapters such as granivory and cavitynesting, they do not appear to be flourishing in urban Manchester. However, in London, Stock Dove appear to be maintaining healthy population in some parks (e.g. Regents Park, eBird 2019). London is a greener city than Manchester ( $23 \%$ covered by greenspace compared to $20.4 \%$, The Guardian, 2017 ) and its parks are larger and older. These more mature parks could provide more suitable habitat for Stock Dove with more natural cavities in older trees, or better connectivity of greenspace for their dispersal needs and potential sensitivity to edges. Further studies are required to compare Stock Dove distribution and abundance across multiple cities to more fully understand the balance between resource availability and Stock Dove habitat requirements in the urban environment.

\section{Declarations}

Acknowledgements

Assistance provided by Chris Sutton from the South Manchester Raptor Group with both Stock Dove records from birds nesting in raptor nest boxes as well as insight into Stock Dove behaviour was greatly appreciated. Detailed information on historical Stock Dove sightings from the members Manchester Birding forums was very valuable. We are particularly grateful to all those who submitted Stock Dove records to eBird during the Survey Period. We would also like to acknowledge Bryan Cosgrove from Manchester City of Trees Team and the GM Combined Authority for providing us with the Manchester City of Trees datasets.

\section{Funding}

No funds, grants, or other support was received.

\section{Conflicts of interest}

The authors have no conflicts of interest to declare that are relevant to the content of this article.

\section{Availability of data and material}

Presence records available via eBird (https://ebird.org/). Habitat variables provided as supplementary material

\section{Code availability}

Available via request to authors 


\section{References}

Aronson M, Lepczyk C, Evans K, Goddard M, Lerman S, Maclvor J, Nilon C, Vargo T (2017) Biodiversity in the city: key challenges for urban green space management. Frontiers in Ecology and the Environment. Wiley-Blackwell, 15(4).

Bar-Massada A, Radeloff VC, Stewart SI (2014) Biotic and Abiotic Effects of Human Settlements in the Wildland-Urban Interface. BioScience 64(5):429-437.

Barnett PR, Whittingham MJ, Bradbury RB, Wilson JD (2004) Use of unimproved and improved lowland grassland by wintering birds in the UK. Agriculture, Ecosystems \& Environment, 102(1):49-60.

Bea A, Svazas S, Grishanov G, Kozulin A, Stanevicius V, Astafieva T, Olano I, Raudonikis L, Butkauskas D, Sruoga, A. (2011) Woodland and Urban Populations of the Woodpigeon Columba palumbus in the Eastern Baltic Region. Ardeola. Spanish Society of Ornithology, 58(2): 315-321.

Beninde J, Veith M, Hochkirch A (2015) Biodiversity in cities needs space: a meta-analysis of factors determining intra-urban biodiversity variation. Ecology Letters, 18:581-592.

BirdLife International (2020) Species factsheet: Columba oenas. [Online] [Accessed: 4th March 2020] http://datazone.birdlife.org/species/factsheet/stock-dove-columba-oenas.

Bradter U, Kunin WE, Altringhan JD, Thorn TJ, Benton TG (2013). Identifying appropriate spatial scales of predictors in species distribution models with the random forest algorithm. Methods Ecol. Evol., 4:167174

BTO (2019a) Bird Track. BTO, Thetford, Norfolk. Available: https://www.bto.org/. [Accessed: 22nd February 2019]

BTO (2019b), Map Store: Breeding Relative Abundance of Stock Dove.

Available: https://app.bto.org/mapstore/StoreServlet?id=269 [Accessed: $11^{\text {th }}$ July 2019]

Buchhorn M, Smets B, Bertels L, De Roo B, Lesiv M, Tsendbazar NE, Herold M, Fritz S (2020). Copernicus Global Land Service: Land Cover 100m: collection 3: epoch 2019: Globe (Version V3.0.1) [Data set]. Zenodo. http://doi.org/10.5281/zenodo.3939050

Centre for Ecology \& Hyrdology (2017). Landcover Map 2015 (LCM2015). [Online] [Accessed: $3^{\text {rd }}$ March 2021] http://mapapps2.bgs.ac.uk/ukso/home.html?layer=CEHLCM2015

Chace JF, Walsh JJ (2006) Urban effects on native avifauna: a review. Landscape and Urban Planning, 74(1):46-69.

Craig S, Selonen V, Koprowski J (2016) Grey squirrel nesting ecology and the use of nest sites in European population management. In, 349-368. 
Crooks KR, Suarez AV, Bolger DT (2004) Avian assemblages along a gradient of urbanization in a highly fragmented landscape. Biological Conservation, 115(3): 451-462.

Davis A, Major RE, Taylor CE (2014) Distribution of tree-hollows and hollow preferences by parrots in an urban landscape. Emu - Austral Ornithology. Taylor \& Francis, 114(4):295-303.

Didham RK, Tylianakis JM, Hutchison MA, Ewers RM, Gemmell NJ (2005) Are invasive species the drivers of ecological change? Trends in Ecology \& Evolution, 20(9):470-474.

eBird (2019) eBird: An online database of bird distribution and abundance [web application]. eBird, Ithaca, New York. Available: https://www.ebird.org/. [Accessed: $2^{\text {nd }}$ January 2019]

European Space Agency (2020) Sentinel Online - ESA. [Online] [Accessed on 6th May 2020] https://sentinel.esa.int/web/sentinel/home.

Fey K, Vuorisalo T, Lehikoinen A, Selonen V (2015) Urbanisation of the wood pigeon (Columba palumbus) in Finland. Landscape and Urban Planning, 134(February):188-194.

Fernández-Juricic E (2000) Avifaunal Use of Wooded Streets in an Urban Landscape. Conservation Biology, 14(2):513-521.

Fernández-Juricic E (2001) Avian spatial segregation at edges and interiors of urban parks in Madrid, Spain. Biodiversity \& Conservation, 10(8):1303-1316.

Forestry Commission (2017). National Forest Inventory for England 2017. Available: https://data.gov.uk/dataset/08312b42-006c-48d9-8ddc-4544d4dbe9bf/national-forestinventory-woodland-england-2017 [Accessed: $27^{\text {th }}$ December 2018]

Fox EW, Hill RA, Leibowitz SG, Olson AR, Thornburgh DJ, Weber MH (2017). Assessing the accuracy and stability of variable selection methods for random forest modeling in ecology. Environ Monit Assess, 189, 316.

Fuller RJ, Chamberlain DE, Burton NHK, Gough SJ (2001) Distributions of birds in lowland agricultural landscapes of England and Wales: How distinctive are bird communities of hedgerows and woodland? Agriculture, Ecosystems \& Environment, 84(1):79-92.

Genuer R, Poggi JM, Tuleau-Malot C (2010) Variable selection using random forests. Pattern Recognition Letters, 31(14):2225-2236.

Goodwin D (1960) Comparative ecology of pigeons in inner London. British Birds, 53(5):201-212.

Hewson CM, Fuller RJ (2003) Impacts of Grey Squirrels on Woodland Birds: An Important Predator of Eggs and Young? The Nunnery, Thetford, Norfolk, IP24 2PU, UK: British Trust for Ornithology. 
Isaksson C (2018) Impact of Urbanization on Birds. In Tietze, D. T. (ed.) Bird Species: How They Arise, Modify and Vanish. Cham: Springer International Publishing (Fascinating Life Sciences):235-257.

Jokimäki J, Suhonen J, Jokimäki-Kaisanlahti ML, Carbó-Ramírez P (2016) Effects of urbanization on breeding birds in European towns: Impacts of species traits. Urban Ecosystems. Springer New York LLC, 19(4) pp. 1565-1577.

Kosiński Z, Bilińska E, Dereziński J, Kempa M (2011) Nest-sites used by Stock Doves Columba oenas: what determines their occupancy? Acta Ornithologica, 46(2).

Lees AC (2018) Interspecific conflict structures urban avian assemblages. Proceedings of the National Academy of Sciences of the United States of America. National Academy of Sciences:12331-12333.

Lepczyk CA, Aronson MFJ, Evans KL, Goddard MA, Lerman SB, Macivor JS (2017) Biodiversity in the City: Fundamental Questions for Understanding the Ecology of Urban Green Spaces for Biodiversity Conservation. BioScience. Oxford University Press:799-807.

Liaw A, Wiener M, (2002) Classification and Regression by randomForest. R News 2(3):18-22.

Manchester Birding (2019) Manchester Birding Forums. [Online] [Accessed: $10^{\text {th }}$ April 2019] https://manchesterbirding.activeboard.com/.

Manchester City of Trees Team and the GM Combined Authority (2019) Manchester City of Trees Audit Data. Salford. (Provided: $19^{\text {th }}$ March 2019). https://www.cityoftrees.org.uk/

Martin AE, Desrochers A, Fahrig L (2017) Homogenization of dispersal ability across bird species in response to landscape change. Oikos. Blackwell Publishing Ltd, 126(7) pp. 996-1003.

McKinney ML (2006) Urbanization as a major cause of biotic homogenization. Biological Conservation. (Urbanization), 127(3):247-260.

Møller AP, Flensted-Jensen E, Nielsen JT (2016) Indirect effects of the generalist avian predator, the goshawk, on life history of an uncommon prey species, the stock dove. Oecologia 182:1045-1052.

Murton RK, Westwood NJ, Isaacson AJ (1964) The Feeding Habits of the Woodpigeon Columba Palumbus, Stock Dove C. Oenas and Turtle Dove Streptopelia Turtur. Ibis, 106(2):174-188.

Natural England (2019) Local Nature Reserves (England). [Online] [Accessed on 15th January 2019] https://naturalengland-defra.opendata.arcgis.com/datasets/local-nature-reserves-england

Newson SE, Leech DI, Hewson CM, Crick HQP, Grice PV (2009) Potential impact of grey squirrels Sciurus carolinensis on woodland bird populations in England. Journal of Ornithology, 151(1):211. 
Newson SE, Johnston A, Parrott D, Leech DI (2011) Evaluating the population-level impact of an invasive species, Ring-necked Parakeet Psittacula krameri, on native avifauna. Ibis, 153(3):509-516.

Nielsen AB, van den Bosch M, Maruthaveeran S, van den Bosch CK (2014) Species richness in urban parks and its drivers: A review of empirical evidence. Urban Ecosystems, 17(1):305-327.

Ó hUallacháin D (2014) Nest Site Location and Success Rates of an Urban Population of Woodpigeon Columba Palumbus in Ireland. Biology and Environment: Proceedings of the Royal Irish Academy. Royal Irish Academy, 114B(1): 13-17.

Open Source Geospatial Foundation (2019) GeoTools: an open source (LGPL) Java code library which provides standards compliant methods for the manipulation of geospatial data. Open Source Geospatial Foundation. Available: https://geotools.org/ Version: 19.4.

OpenStreetMap contributors (2015) Planet dump [Data file included with QGIS].

Ordnance Survey (2018a) OS Open Greenspace: the location of public parks, playing fields, sports facilities, play areas and allotments. Includes function and name.

Available: https://www.ordnancesurvey.co.uk/business-government/products/open-map-greenspace [Accessed: 23 ${ }^{\text {rd }}$ December 2018]

Ordnance Survey (2018b) OS Open Master Map Topography: the most detailed and accurate view of Great Britain's landscape - from roads to fields, to buildings and trees, fences, paths and more. Available: https://www.ordnancesurvey.co.uk/business-government/products/mastermap-topography [Accessed: $16^{\text {th }}$ January 2019]

Ordnance Survey (2018c) OS Open Roads: Motorways, A-roads, B-roads, road classification, road name, primary route information, motorway junction information.

Available: https://www.ordnancesurvey.co.uk/business-government/products/open-map-roads [Accessed: $21^{\text {st }}$ December 2018]

Phillips SJ, Dudík M, Schapire RE (2019) Maxent software for modelling species niches and distributions (Version 3.4.1). Available: http://biodiversityinformatics.amnh.org/open_source/maxent/. [Accessed:

February 2019]

Purevdorj TS, Tateishi R, Ishiyama T, Honda Y (1998) Relationships between percent vegetation cover and vegetation indices, International Journal of Remote Sensing, 19:18:3519-3535

QGIS Development Team (2019) QGIS Geographic Information System. Open Source Geospatial Foundation Project. http://qgis.osgeo.org. Version: 3.8.3

Robinson RA (2005) BirdFacts: profiles of birds occurring in Britain \& Ireland. BTO, Thetford (http://www.bto.org/birdfacts, accessed on 24 February 2021) 
RStudio Team (2015) RStudio: Integrated Development for R. RStudio, Inc., Boston, MA URL http://www.rstudio.com/ Version: 1.2.5042

Šálek M, Svobodová J, Zasadil P (2010) Edge effect of low-traffic forest roads on bird communities in secondary production forests in central Europe. Landscape Ecology, 25(7):1113-1124.

Shochat E, Warren PS, Faeth SH, Mclntyre NE, Hope D (2006) From patterns to emerging processes in mechanistic urban ecology. Trends Ecol Evol 21:186-191

Snow D, David W, Perrins C, Gillmor R (1998) The birds of the western palearctic. Vol 1, Non-passerines. Concise ed., Oxford: Oxford University Press.

Sol D, González-Lagos C, Moreira D, Maspons J, Lapiedra 0 (2014) Urbanisation tolerance and the loss of avian diversity. Ecology Letters, 17(8):942-950.

Spotswood EN, Beller EE, Grossinger R, Grenier JL, Heller NE, Aronson MFJ (2021) The Biological Deserts Fallacy: Cities in Their Landscapes Contribute More than We Think to Regional Biodiversity. BioScience. Oxford University Press (OUP), January.

Strubbe D and Matthysen E (2007) Invasive ring-necked parakeets Psittacula krameri in Belgium: habitat selection and impact on native birds. Ecography, 30(4):578-588.

Struebig MJ, Turner A, Giles E, Lasmana F, Tollington S, Bernard H, Bell D (2013) Chapter Three Quantifying the Biodiversity Value of Repeatedly Logged Rainforests: Gradient and Comparative Approaches from Borneo. In Woodward G and O'Gorman EJ (eds) Advances in Ecological Research. Academic Press (Global Change in Multispecies Systems: Part 3):183-224.

The Guardian (2017) How green is your city? UK's top 10 mapped and ranked. Cities. [Online] 5th January. [Accessed on 6th May 2020] https://www.theguardian.com/cities/gallery/2017/jan/05/green-space-uklargest-cities-mapped.

Werner P (2011) The ecology of urban areas and their functions for species diversity. Landscape and Ecological Engineering, 7(2):231-240.

With KA, King AW (2001) Analysis of landscape sources and sinks: the effect of spatial pattern on avian demography. Biological Conservation, 100(1):75-88.

Woodward I, Aebischer N, Burnell D, Eaton M, Frost T, Hall C, Stroud DA, Noble D (2020) Population estimates of birds in Great Britain and the United Kingdom. British Birds 113:69-104.

\section{Tables}




\begin{tabular}{|c|c|c|}
\hline Variable & Unit & Scales \\
\hline Density of individual trees over $\mathrm{X}$ metres * & $\begin{array}{l}\text { trees } \\
\mathrm{km}^{-2}\end{array}$ & $12,14,16,18,20,22$ and $24 \mathrm{~m}$ \\
\hline $\begin{array}{l}\text { Total area covered by canopy of individual trees over } \\
\text { X metres * }\end{array}$ & $\mathrm{km}^{2}$ & $12,14,16,18,20,22$ and $24 \mathrm{~m}$ \\
\hline $\begin{array}{l}\text { BTO Relative Abundance within X km around } \\
\text { patch }+\end{array}$ & $0-9$ & $\begin{array}{l}0.5 \mathrm{~km}, 1 \mathrm{~km} \text {, and then every } \mathrm{km} \\
\text { to } 13 \mathrm{~km}\end{array}$ \\
\hline Average NDVI within $X$ metres around patch $¥$ & NDVI & Every $50 \mathrm{~m}$, from $50 \mathrm{~m}$ to $1000 \mathrm{~m}$. \\
\hline Woodland cover * & $\mathrm{km}^{2}$ & - \\
\hline Percentage of total area covered by woodland * & $\%$ & - \\
\hline Maximum individual tree height * & $\mathrm{m}$ & - \\
\hline Average individual tree height * & $\mathrm{m}$ & - \\
\hline Water cover $\S$ & $\mathrm{km}^{2}$ & - \\
\hline Distance to water $\S$ & $\mathrm{m}$ & - \\
\hline Grassland cover \| & $\mathrm{km}^{2}$ & - \\
\hline Percentage of total area covered by grassland \|| & $\%$ & - \\
\hline Total area 9 & $\mathrm{~km}^{2}$ & - \\
\hline Distance from centre of Manchester \# & $\mathrm{km}$ & - \\
\hline Function of the greenspace ** & - & - \\
\hline Land cover smoothness $+\dagger$ & - & - \\
\hline
\end{tabular}

Table 1: Predictor variables explored; scales given when multiple scales were investigated.

* Measured from Manchester City of Trees Team and the GM Combined Authority (2019). This contains two datasets for trees across Greater Manchester. The first is a Lidar dataset for individual trees and includes the height and canopy cover of each tree. The second is for denser areas of woodland where individual trees could not be measured by Lidar and only includes the area covered by that woodland. This allows large individual trees to be identified but adds complexity by spreading tree data across two datasets.

† Measured from relative abundance maps published by the BTO (British Trust for Ornithology) (BTO, 2019b). These maps contain 10 levels from 0 to 9 with 9 being the highest relative abundance.

¥ Measured from imagery published by European Space Agency (2020). The image from the 29 June 2018 was used as being the day closest to the survey period with $0 \%$ clouds and including all of 
Manchester. The $20 \times 20 \mathrm{~m}$ pixel image was used as a compromise between accuracy and computation speed.

$\S$ Measured from OS Open MasterMap (Ordnance Survey, 2018b). Includes all topography with a theme of water.

\| Measured from vectors using QGIS (QGIS Development Team, 2019). Includes all topography with a theme of land, a primary description of general surface, an empty secondary description, and a make of natural.

१ Measured from vectors using QGIS (QGIS Development Team, 2019).

\# Measured from vectors using QGIS (QGIS Development Team, 2019). Centre of Manchester defined as Albert Square at (383797, 398105; EPSG:27700)

** Function from Ordnance Survey Greenspace dataset (Ordnance Survey, 2018a), LNR, or Brownfield t† The standard deviation of the percentage grassland and woodland cover.

\section{Table 2}

\begin{tabular}{|c|c|c|c|c|c|}
\hline Variable & I & $P$ & $\begin{array}{l}\text { Mean } \pm \text { SD for } \\
\text { Presence patches }\end{array}$ & $\begin{array}{l}\text { Mean } \pm \text { SD for } \\
\text { Absence patches }\end{array}$ & $\begin{array}{l}\text { Wilcox Test } \\
\text { (p-value) }\end{array}$ \\
\hline $\begin{array}{l}\text { Average BTO Relative } \\
\text { Abundance within } 13 \mathrm{~km}\end{array}$ & Y & Y & $3.6 \pm 0.4$ & $3.2 \pm 0.6$ & $<0.0001$ \\
\hline NDVI within $0.5 \mathrm{~km}$ & Y & Y & $0.53 \pm 0.11$ & $0.46 \pm 0.10$ & 0.001 \\
\hline $\begin{array}{l}\text { Canopy Cover of individual trees } \\
\text { over } 20 \mathrm{~m}\left(\mathrm{~km}^{2}\right)\end{array}$ & Y & $Y$ & $0.008 \pm 0.010$ & $0.005 \pm 0.012$ & 0.03 \\
\hline $\begin{array}{l}\text { Tree density of individual trees } \\
\text { over } 20 \mathrm{~m} \text { (trees } \mathrm{km}^{-2} \text { ) }\end{array}$ & & Y & $99.1 \pm 125.9$ & $113.6 \pm 190.2$ & 0.3 \\
\hline $\begin{array}{l}\text { Maximum individual tree height } \\
\text { (m) }\end{array}$ & & $Y$ & $26.7 \pm 4.5$ & $23.2 \pm 5.1$ & 0.02 \\
\hline Total area $\left(\mathrm{km}^{2}\right)$ & & & $0.51 \pm 0.69$ & $0.24 \pm 0.19$ & 0.6 \\
\hline
\end{tabular}

Table 2: Variables selected for Interpretation $(I)$ and Prediction $(P)$ from the variables remaining after stage 2 of variable selection. Wilcox tests used to compare the means of patches with and without Stock Dove. 


\section{Table 3}

\begin{tabular}{|c|c|c|c|}
\hline Variable & $\begin{array}{l}\text { Mean } \pm \text { SD for } \\
\text { Breeding Season }\end{array}$ & $\begin{array}{l}\text { Mean } \pm \text { SD for Non- } \\
\text { Breeding Season }\end{array}$ & $\begin{array}{l}\text { Wilcox Test } \\
\text { p-value }\end{array}$ \\
\hline $\begin{array}{l}\text { Average BTO Relative Abundance } \\
\text { within } 13 \mathrm{~km}\end{array}$ & $3.70 \pm 0.46$ & $3.62 \pm 0.48$ & 0.37 \\
\hline Average NDVI within $0.5 \mathrm{~km}$ & $0.54 \pm 0.13$ & $0.55 \pm 0.13$ & 0.41 \\
\hline $\begin{array}{l}\text { Canopy Cover of individual trees } \\
\text { over } 20 \mathrm{~m}\left(\mathrm{~km}^{2}\right)\end{array}$ & $0.007 \pm 0.011$ & $0.010 \pm 0.014$ & 0.21 \\
\hline $\begin{array}{l}\text { Tree density of individual trees } \\
\text { over } 20 \mathrm{~m} \text { (trees } \mathrm{km}^{2} \text { ) }\end{array}$ & $57.5 \pm 99.4$ & $42.1 \pm 81.7$ & 0.70 \\
\hline Max tree height (m) & $23.5 \pm 7.06$ & $24.9 \pm 6.51$ & 0.29 \\
\hline Total area $\left(\mathrm{km}^{2}\right)$ & $0.62 \pm 0.79$ & $0.89 \pm 1.01$ & 0.22 \\
\hline $\begin{array}{l}\text { Total area covered by grassland } \\
\left(\mathrm{km}^{2}\right)\end{array}$ & $0.19 \pm 0.30$ & $0.30 \pm 0.38$ & 0.06 \\
\hline Total area covered by water $\left(\mathrm{km}^{2}\right)$ & $0.09 \pm 0.13$ & $0.14 \pm 0.15$ & 0.007 \\
\hline Distance to city centre (km) & $5.59 \pm 1.69$ & $5.90 \pm 1.60$ & 0.17 \\
\hline
\end{tabular}

Table 3: Differences between predictor variables for patches with citizen science Stock Dove records in the breeding season (March - August) and the non-breeding season (September - February).

\section{Figures}



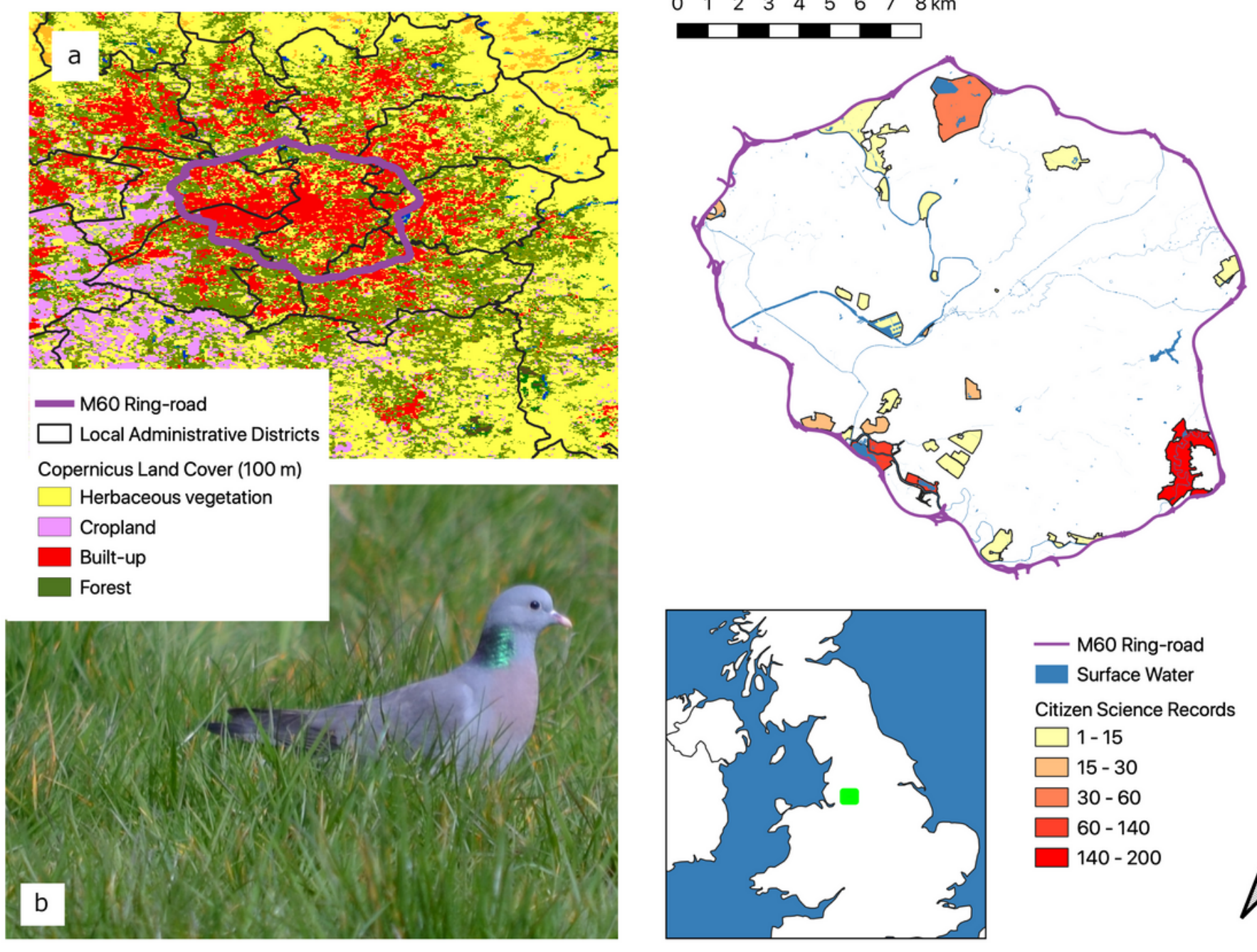

- M60 Ring-road

Surface Water

Citizen Science Records

$\square$ - 15

$\square 15-30$

$\square 30-60$

ए $60-140$

$140-200$

\section{Figure 1}

(a) Land cover in the region surrounding Manchester (Buchhorn et al 2020). (b) Urban Stock Dove in Alexandra Park (April 2020). (c) Patches with previous Stock Dove Sightings inside the Manchester M60 Ring-Road from Citizen Science sources. 


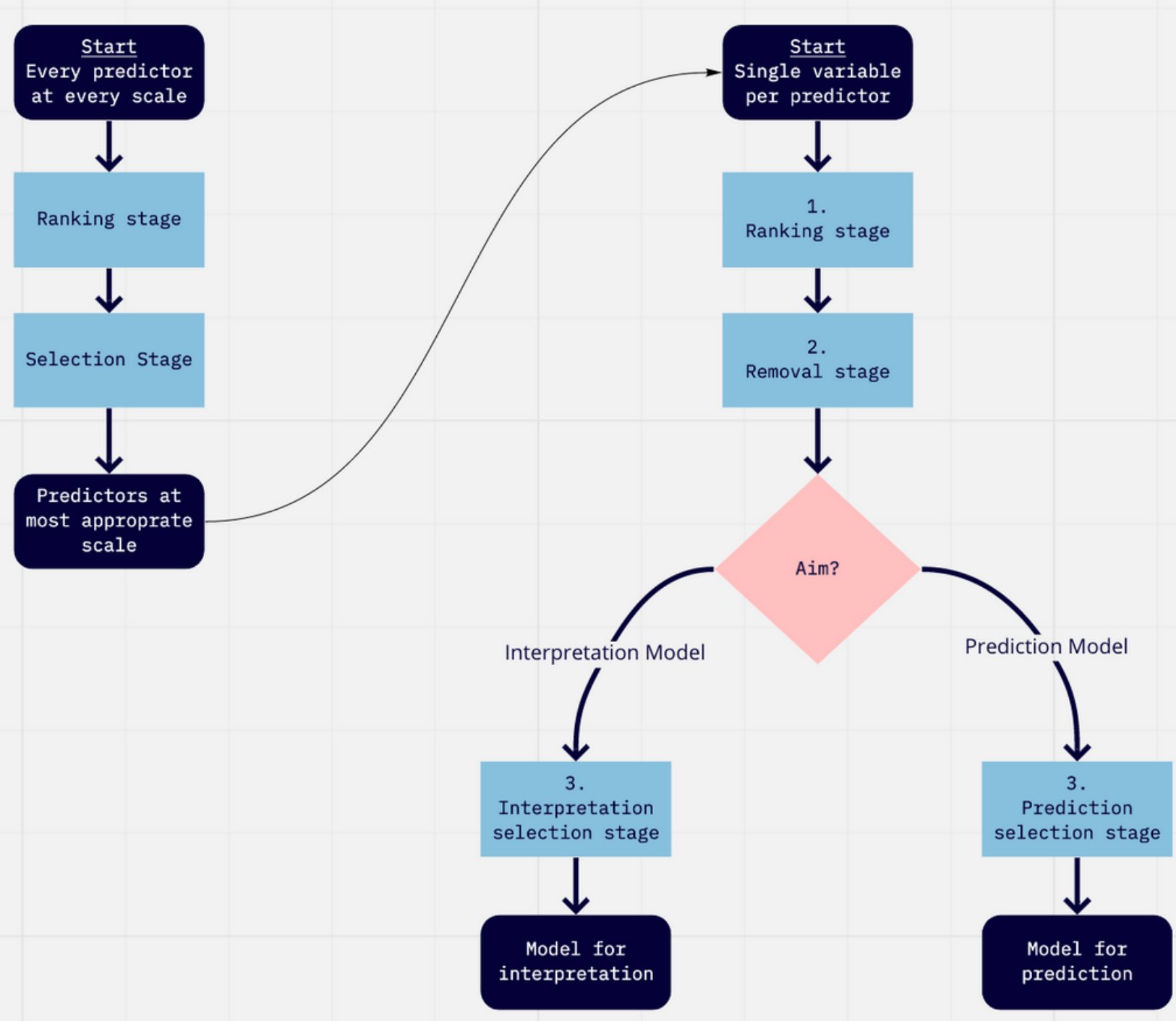

Figure 2

The initial selection of scaled predictors (left), followed by the three stages of model selection based on the method described by Genuer et al. (2010) (right). 

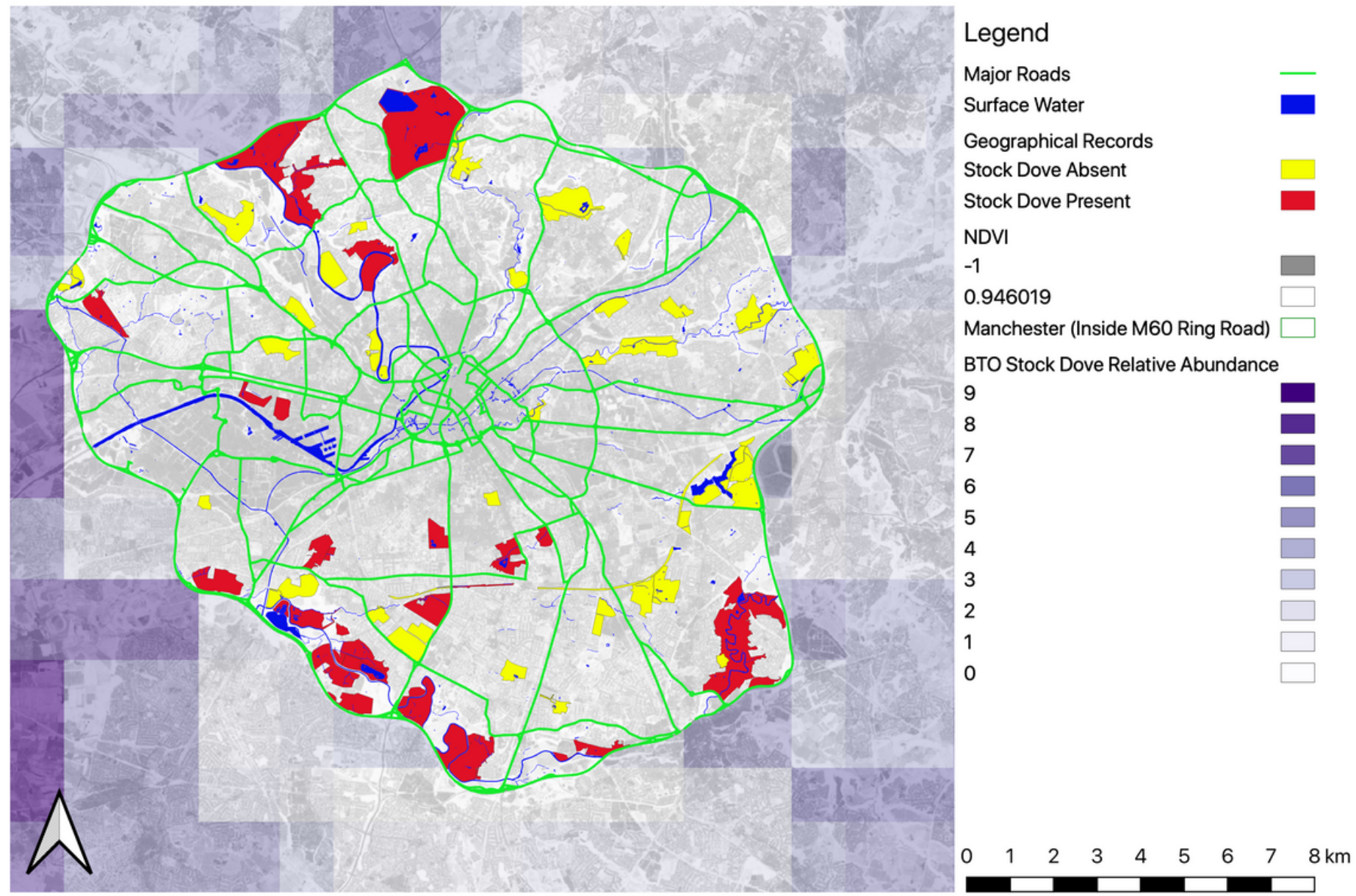

Figure 3

The 65 sample patches across Manchester showing where Stock Dove were present and absent. Base layers for some predictor variables are shown including NDVI, BTO Relative Abundance (outside of the M60 only) and surface water. 


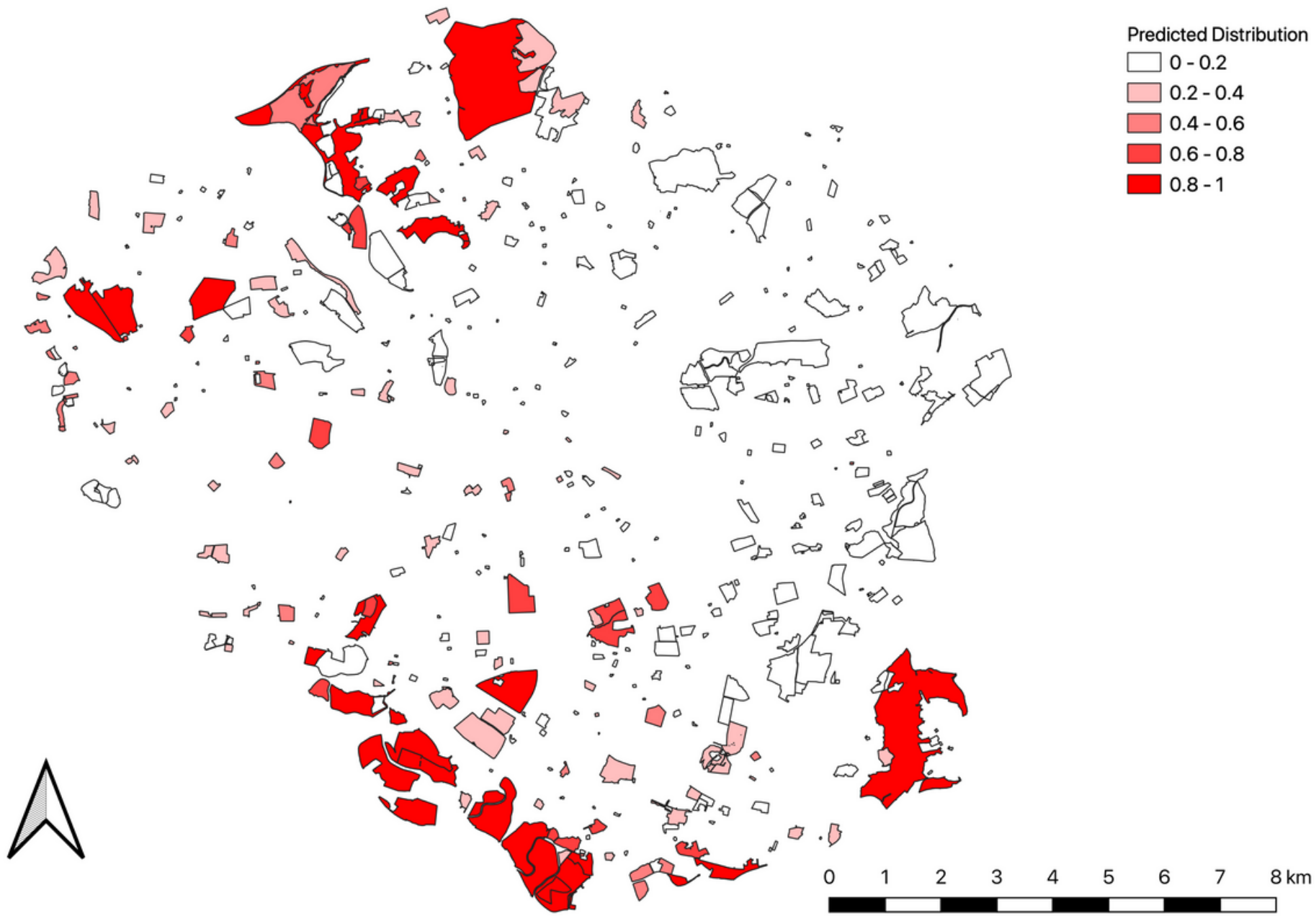

Figure 4

Each patch from the OS Greenspace dataset (Ordnance Survey, 2018a) with the probability of Stock Dove presence calculated using the $\mathrm{R}$ random forest package (Liaw and Wiener, 2002) using the model selected for prediction (Table 2).

\section{Supplementary Files}

This is a list of supplementary files associated with this preprint. Click to download.

- fieldsurvey.csv

- historicdata.csv 